\title{
ANALISIS EFISIENSI SALURAN DISTRIBUSI DAN RISIKO PELAKU USAHA PADA RANTAI PASOK IKAN CAKALANG ASAP DI KELURAHAN GIRIAN ATAS KOTA BITUNG PROVINSI SULAWESI UTARA

\author{
Maghelhais Takalamingan'; Florence V. Longdong2; Alvon Jusuf ${ }^{2}$ \\ 1) Mahasiswa Fakultas Perikanan dan IImu Kelautan Universitas Sam Ratulangi, Manado. \\ 2) Staff Pengajar Fakultas Perikanan dan IImu Kelautan Universitas Sam Ratulangi, Manado. \\ Koresponden email: magheltakalamingan08@gmail.com
}

\begin{abstract}
This study aims to identify product flow, financial flow and information flow on the supply chain of smoked skipjack fish, to analyze the efficiency level of distribution channel in the supply chain, and to identify risks faced by each business actor in smoked skipjack supply chain in Kelurahan Girian Atas, Bitung City, North Sulawesi Province.

The method used in this research is case study. The sample of 12 respondents was taken by purposive sampling method. The data were collected by interview based on the prepared questionnaire. The data collected were analyzed by qualitative methods and simple quantitative methods to calculate the efficiency of distribution channels and risks faced by business actors.

Supply chain of smoked skipjack fish in Kelurahan Girian Atas, Bitung City, consists of 5 (five) business actors, namely traders of fresh skipjack fish, skipjack fish processors, smoked skipjack fish wholesalers, smoked skipjack fish retailers and restaurants as consumers. There are two distribution channels formed in the supply chain of smoked skipjack fish. In general, the two distribution channels were considered efficient because the ratio of average transaction costs to the average product value is less than $50 \%$. Totally there are 18 risks that occur from 5 (five) of the supply chain actors. Price fluctuations are the most common risk to all supply chain actors of skipjack fish in Kelurahan Girian Atas, Bitung City.
\end{abstract}

Keywords: distribution efficiency, smoked skipjack fish

\begin{abstract}
Abstrak
Penelitian ini bertujuan untuk mengidentifikasi aliran produk, aliran keuangan dan aliran informasi pada rantai pasok ikan cakalang asap, menganalisis tingkat efisiensi saluran distribusi pada rantai pasok ikan cakalang asap, dan mengidentifikasi risiko yang dihadapi pada setiap pelaku usaha pada rantai pasok ikan cakalang asap di Kelurahan Girian Atas, Kota Bitung, Provinsi Sulawesi Utara.

Metode yang digunakan dalam penelitian ini adalah studi kasus. Sampel sebanyak 12 orang responden diambil dengan metode purposive sampling. Pengumpulan data dilakukan dengan wawancara berdasarkan kuesioner yang telah disiapkan sebelumnya. Data yang telah dikumpulkan dianalisis dengan metode kualitatif dan metode kuantitatif sederhana untuk menghitung efisiensi saluran distribusi dan resiko yang dihadapi oleh pelaku usaha.

Rantai pasok ikan cakalang asap di Kelurahan Girian Atas Kota Bitung terdiri dari 5 (lima) pelaku usaha, yaitu pedagang ikan cakalang segar, pengolah ikan cakalang asap, pedagang besar ikan cakalang asap, pedagang pengecer ikan cakalang asap dan rumah makan sebagai konsumen. Ada dua saluran distribusi yang terbentuk pada rantai pasok ikan cakalang asap. Secara umum kedua saluran distribusi telah masuk kategori efisien karena rasio rata-rata biaya transaksi terhadap rata-rata nilai produk kurang dari $50 \%$. Secara total ada 18 risiko yang terjadi dari 5 (lima) para pelaku rantai pasok. Fluktuasi harga menjadi risiko yang paling banyak terjadi pada seluruh pelaku rantai rantai pasok ikan cakalang asap di Kelurahan Girian Atas Kota Bitung.
\end{abstract}

Kata kunci : efisiensi distribusi, ikan cakalang asap.

\section{PENDAHULUAN}

Pembangunan sektor perikanan

dan kelautan merupakan kegiatan pemanfaatan sumberdaya alam yang diarahkan dengan sasaran utama pencukupan kebutuhan pangan, peningkatan kesempatan kerja, peningkatan pendapatan devisa, dan pemeliharaan usaha serta lingkungan yang lestari. Sebagai bagian dari pembangunan nasional, pembangunan perikanan bertujuan untuk mengusahakan agar setiap kegiatan di sektor ini dapat dilakukan oleh bangsa Indonesia, yang mencakup kegiatan produksi, pengolahan maupun pemasaran (Dahuri dkk., 2001).

Sebagai salah satu cara pengawetan, proses pengasapan ikan secara keseluruhan merupakan penggabungan dari proses penggaraman, pengeringan dan 
pemberian asap. Pengasapan ikan memiliki beberapa kelebihan, yaitu dapat mengawetkan ikan dan menambah cita rasa sehingga dapat menarik minat konsumen untuk membeli produk ini. Pengasapan ikan sering dilakukan untuk memanfaatkan hasil tangkap ikan yang berlebih pada saat musim panen ikan, atau untuk memperpanjang masa simpan karena ikan tidak segera terjual. Dengan teknologi pengasapan yang spesifik, ikan memungkinkan untuk disimpan lebih lama sampai musim paceklik sehingga dapat meningkatkan ketersediaan protein bagi masyarakat sepanjang tahun. Ikan asap menjadi awet karena adanya pengurangan kadar air akibat dari proses pemanasan dan adanya senyawa-senyawa kimia di dalam asap seperti senyawa fenol yang dapat menghambat pertumbuhan mikroorganisme dan berperan sebagai antioksidan. Pengasapan juga memberikan warna, tekstur dan flavor yang khas pada ikan (Dulay dkk., 2014).

Penelitian terhadap sistem rantai pasok ikan cakalang asap dan identifikasi risiko yang dihadapi oleh para pelaku usaha diperlukan untuk mengetahui permasalahan sehingga ketersediaan dan kualitas produk dapat dipertahankan dalam kondisi yang baik, kepuasan konsumen terpenuhi, dan para pelaku usaha yang terlibat dalam rantai pasok ikan cakalang asap tidak menderita kerugian.

\section{METODE PENELITIAN}

Metode yang digunakan dalam penelitian ini adalah studi kasus. Sampel sebanyak 12 orang responden diambil dengan metode purposive sampling. Pengumpulan data dilakukan dengan wawancara berdasarkan kuesioner yang telah disiapkan sebelumnya. Data yang telah dikumpulkan dianalisis dengan metode kualitatif dan metode kuantitatif sederhana untuk menghitung efisiensi saluran distribusi dan resiko yang dihadapi oleh pelaku usaha.

\section{HASIL DAN PEMBAHASAN Jaringan Distribusi Rantai Pasok Ikan Cakalang Asap}

Struktur Jaringan distribusi rantai pasok ikan cakalang asap pada umumnya memiliki beberapa karakteristik yang sama. Pola aliran dalam rantai pasok ikan cakalang asap menunjukkan ada tiga aliran yaitu berupa aliran produk, aliran keuangan dan aliran informasi. Aliran produk ikan cakalang segar yaitu dari pedagang perantara ikan cakalang segar yang berlokasi di tempat pelelangan ikan ke tempat pengolahan ikan cakalang asap di Kelurahan Girian Atas. Sedangkan aliran produk berupa ikan cakalang asap, dimulai dari tempat pengolahan ikan cakalang asap Kelurahan Girian atas ke pedagang pengecer di Pasar Bersahati dan Pasar Karombasan hingga konsumen akhir. Aliran keuangan mengalir dari hilir ke hulu yaitu dari konsumen ikan cakalang asap dan konsumen pengolah ikan cakalang asap ke pedagang ikan cakalang segar. Aliran informasi mengalir pada mata rantai secara timbal balik.

\section{Aliran Produk Ikan Cakalang Asap}

Aliran produk merupakan aliran barang dari hulu ke hilir. Produk dalam rantai pasok ini yaitu ikan cakalang asap. Rantai pasok dimulai dari ikan cakalang segar sebagai bahan baku utama yang dijual ke tempat pengolahan ikan cakalang asap. Ikan cakalang segar yang akan di olah berasal dari pedagang perantara di tempat pelelangan ikan Kecamatan Aertembaga. Tempat pelelangan ikan adalah tempat transaksi 
pembelian ikan cakalang segar yang biasanya dilakukan pada pagi hari. Ratarata pengolah ikan cakalang asap di Kelurahan Girian Atas sudah memiliki langganan tetap untuk membeli bahan baku ikan sehingga kapan saja memerlukan pasokan ikan segar bisa langsung dihubungi.

Aliran selanjutnya berupa ikan cakalang asap yang siap untuk dijual. Produsen yang adalah distributor atau pedang besar ikan cakalang asap menjual produknya kepada pedagang pengecer sebanyak yang dibutuhkan kemudian pedagang pengecer menjualnya di tempat penjualan ikan cakalang asap dan pasar-pasar tradisional yaitu pasar Bersahati dan Pasar Karombasan. Konsumen ikan cakalang asap sebagian besar adalah ibu-ibu rumah tangga dan pemilik rumah makan. Produk olahan ikan cakalang asap bisa dikatakan sangat digemari walaupun harganya lumayan mahal, namun hal itu sebanding dengan cita rasa yang khas serta daya tahan produk yang tidak mudah rusak walaupun di simpan dalam jangka waktu yang cukup lama.

\section{Aliran Keuangan Pada Rantai Pasok Ikan Cakalang Asap}

Aliran Keuangan merupakan perpindahan uang yang mengalir dari hilir ke hulu. Aliran keuangan pada penelitian ini terbagi menjadi dua, yaitu aliran keuangan yang mengalir dari pengolah ikan cakalang asap pada pedagang ikan cakalang segar dan konsumen ikan cakalang asap hingga distributor atau pedagang besar ikan cakalang asap. Sistem pembayaran dilakukan secara tunai dan pembayaran secara tempo. Konsumen ikan cakalang asap melakukan pembayaran secara tunai kepada pedagang pengecer ikan cakalang asap dan begitu juga pedagang pengecer ke pedagang besar ikan cakalang asap. Pembayaran dilakukan secara langsung ditempat produk tersebut diperoleh. Harga ikan cakalang asap yang dijual oleh distributor ke pedagang pengecer adalah Rp 30.000 untuk ikan yang berukuran 0,5 kg dan Rp 60.000 untuk ukuran 1,2 $\mathrm{kg}$. Selanjutnya untuk harga jual pedagang pengecer ke konsumen adalah Rp 40.000 untuk ukuran $0.5 \mathrm{~kg}$ dan Rp 75.000 untuk ikan cakalang asap yang berukuran $1,2 \mathrm{~kg}$.

Pengolah ikan cakalang asap yang membeli ikan cakalang segar dari pedagang perantara dengan melakukan pembayaran secara tunai dan tempo sesuai dengan kesepakatan antara pedagang dan pengolah. Pembayaran secara tempo dilakukan selama satu hingga dua minggu namun terlebih dahulu membayar Down Payment (DP) sebesar $50 \%$ kepada pedagang ikan cakalang segar. Biasanya jumlah pembelian bahan baku ikan segar dapat berkisar 500 - $1.000 \mathrm{~kg}$ dalam waktu satu minggu dengan harga Rp 25.000 per kg.

\section{Aliran Informasi Pada Rantai Pasok Ikan Cakalang Asap}

Aliran informasi merupakan aliran yang terjadi baik dari hulu ke hilir maupun sebaliknya dari hilir ke hulu. Informasi yang mengalir berkaitan dengan stok ikan cakalang segar, jumlah permintaan, harga ikan cakalang segar, harga ikan cakalang asap.

Terdapat beberapa aliran informasi yang mengalir secara vertikal antar mata rantai dalam rantai pasokan ikan cakalang asap, yaitu : 
1. Antara pengolah ikan cakalang asap dengan pedagang ikan cakalang segar

Aliran informasi yang terjadi antara pengolah ikan cakalang asap dan pedagang ikan cakalang segar berkaitan dengan jumlah ikan yang dibutuhkan pengolah untuk memenuhi kebutuhan produksi. Kesesuaian harga dan kondisi ikan yang dibeli menjadi objek utama dalam komunikasi yang terjalin antara pedagang ikan segar dan pengolah ikan cakalang asap. Pengolah yang membutuhkan ikan cakalang segar biasanya menghubungi atau mendatangi langsung setelah pedagang menyiapkan ikan segar sesuai dengan kriteria yang diinginkan pengolah.

2. Antara Pedagang Pengecer dan Distributor/Pedagang Besar Ikan Cakalang Asap

Aliran informasi antara distributor atau pedagang besar ikan cakalang asap dengan pedagang pengecer terkait dengan jumlah produk ikan cakalang asap yang akan dibeli oleh pedagang pengecer untuk dijual lagi ke konsumen, jumlah stok ikan cakalang asap dan harga ikan cakalang asap di tingkat pedagang pengecer. Informasi yang mengalir dari pedagang pengecer ke pedagang besar berkaitan dengan jumlah ikan cakalang asap yang terjual setiap harinya.

\section{Antara Konsumen dan Pedagang Pengecer}

Konsumen ikan cakalang asap adalah orang yang melakukan pembelian yang sebagian besar adalah Ibu Rumah Tangga maupun pengolah rumah makan. Aliran informasi terjadi antara konsumen ke pedagang pengecer terkait dengan jumlah permintaan ikan cakalang asap. Adanya informasi jumlah permintaan dari konsumen berpengaruh terhadap jumlah dan ukuran ikan cakalang asap yang akan dibeli. Informasi tersebut akan mengalir kepada pedagang besar agar mampu memperkirakan jumlah ikan asap yang harus dihasilkan dan disesuaikan dengan kondisi transaksi jual-beli.

Upaya untuk mengoptimalkan ketiga aliran yang ada pada rantai pasokan ikan cakalang asap dapat dilakukan dengan pendekatan sistem dengan melibatkan beberapa pihak, seperti pedagan ikan cakalang segar, pengolah ikan cakalang asap, pedagang besar ikan cakalang asap, pedagang pengecer, konsumen dan pihak pemerintah sebagai penentu kebijakan.

\section{Analisis Efisiensi Saluran Distribusi Ikan Cakalang Asap}

Produk yang didistribusikan dalam menganalisis efisiensi saluran distribusi, yaitu berupa rantai pasok ikan cakalang asap. Saluran distribusi ikan cakalang asap di Kelurahan Girian Atas Kota Bitung memiliki 2 (dua) saluran alternatif. Saluran distribusi ikan cakalang asap di Kelurahan Girian Atas Kota Bitung dapat dilihat pada Gambar berikut. 


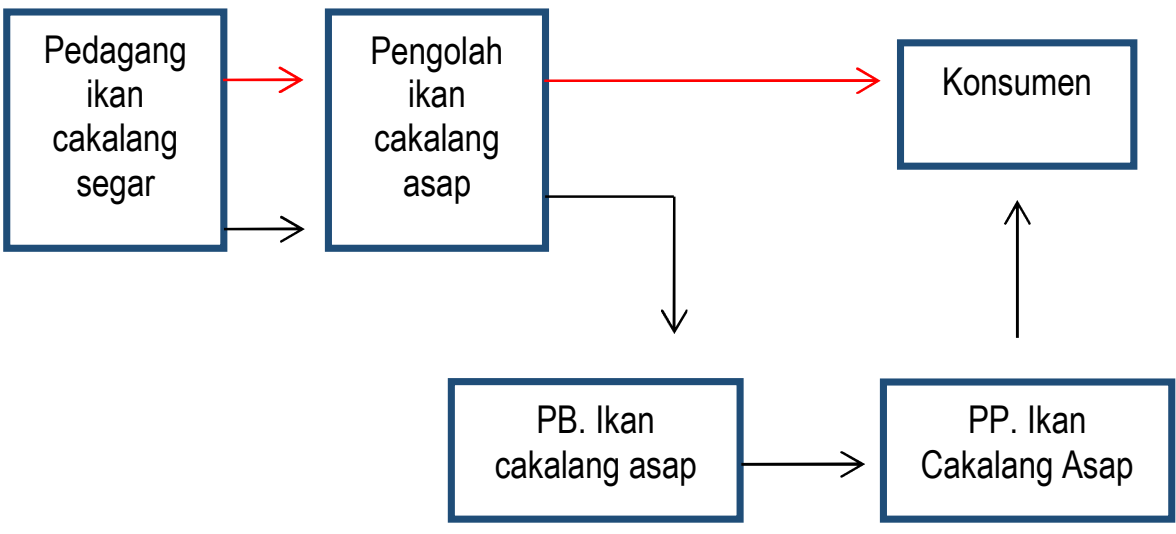

Keterangan

Gambar 1. Saluran Distribusi Ikan Cakalang Asap

Săluran I

: Pedagang ikan cakalang segar - Pengolah ikan cakalang asap konsumen.

Sałuran II : Pedagang Ikan Cakalang Segar - Pengolah Ikan Cakalang Asap Pedagang besar ikan cakalang asap - Pedagang perantara ikan cakalang asap - Konsumen.

\section{Biaya Pemasaran}

Biaya pemasaran merupakan biaya yang harus dikeluarkan untuk keperluan pemasaran. Secara keseluruhan biaya pemasaran ikan cakalang asap yaitu transportasi, bea,

Tabel. Biaya Pemasaran dalam Sehari

\begin{tabular}{|c|c|c|c|}
\hline \multirow{2}{*}{ No. } & \multirow{2}{*}{ Uraian } & Saluran 1 & Saluran 2 \\
\hline & & Biaya (Rp) & Biaya (Rp) \\
\hline 1 & Biaya transportasi & 150.000 & 50.000 \\
\hline 2 & Biaya tenaga kerja & 200.000 & 100.000 \\
\hline 3 & Sewa lapak/kios & 28.000 & 28.000 \\
\hline 4 & Biaya retribusi & 10.000 & 10.000 \\
\hline & Jumlah & 388.000 & 238.000 \\
\hline
\end{tabular}

Sumber : Data Primer, 2017 resiko kerusakan. Besarnya biaya yang dikeluarkan bagi setiap saluran selalu berbeda-beda. Dengan demikian semakin panjang saluran pemasaran maka jumlah biaya yang dikeluarkan akan semakin bertambah.

\section{Biaya Produksi}

Menurut Mulyadi (2005) biaya produksi merupakan biaya-biaya yang terjadi untuk mengolah bahan baku menjadi produk jadi yang siap untuk dijual, seperti bahan baku ikan, bambu, daun palem (woka), sabut kelapa, dan pewarna makanan.

Tabel. Biaya Produksi dalam Waktu Satu Hari

\begin{tabular}{|c|c|c|c|c|}
\hline No. & Uraian & Kuantitas & Harga satuan (Rp) & Biaya (Rp) \\
\hline 1 & Ikan cakalang mentah & 100 ekor & 25.000 & 2.500 .000 \\
\hline 2 & Transportasi & 1 kali & 150.000 & 150.000 \\
\hline 3 & Bambu & 2 ujung & 10.000 & 20.000 \\
\hline 4 & Daun palem (woka) & 5 ujung & 5.000 & 25.000 \\
\hline 5 & Sabut kelapa & 1 drop & 200.000 & 200.000 \\
\hline 6 & Pewarna makanan & $1 \mathrm{~kg}$ & 100.000 & 100.000 \\
\hline 7 & Tenaga kerja & 4 orang & 150.000 & 600.000 \\
\hline 8 & Penyusutan & & & 131.000 \\
\hline 9 & Gaji pemilik & 1 orang & 250.000 & 250.000 \\
\hline \multicolumn{2}{|r|}{ Jumlah } & & & 3.976 .000 \\
\hline
\end{tabular}

Sumber : Data Primer, 2017 


\section{Margin Pemasaran}

$M p=P r-P f$

Diketahui : Harga ikan cakalang asap

per jepit

Produsen : Rp 30.000

Konsumen : Rp 40.000

$\mathrm{Mp}=\mathrm{Rp} 40.000-\operatorname{Rp} 30.000$

$M p=\operatorname{Rp} 10.000$

Tingkat Produsen $\operatorname{Rp} 30.000 \times 200$ jepit $=$

Rp 6.000.000

Tingkat Konsumen Rp $40.000 \times 200$ jepit =

Rp 8.000.000

Selisih harga Rp 8.000.000 - Rp 6.000.000 =

Rp 2.000.000

Jadi selisih harga yang diterima

oleh produsen dan harga yang dibayar oleh konsumen selama produksi 1 hari yaitu $R p$ 2.000.000.

Keuntungan pengolah/hari $=\operatorname{Rp} 6.000 .000-$ $\operatorname{Rp} 3.976 .000=\operatorname{Rp} 2.024 .000$

Masing-masing saluran dihitung total biaya pembelian, biaya transaksi, rata-rata volume pasokan harian, untuk menentukan saluran distribusi ikan cakalang asap yang paling efisien. Hasil perhitungan disajikan dalam Tabel berikut.

Tabel. Efisiensi Saluran Distribusi Ikan Cakalang Asap

\begin{tabular}{|c|c|c|c|c|}
\hline Saluran & $\begin{array}{c}\text { Rata-rata Pasokan } \\
\text { (Jepit/hari) }\end{array}$ & $\begin{array}{c}\text { Rata-rata Nilai Produk } \\
\text { (Rp/jepit) } \\
(\mathrm{a})\end{array}$ & $\begin{array}{c}\text { Rata-rata Biaya } \\
\text { Transaksi (Rp/jepit) } \\
(\mathrm{b})\end{array}$ & $\begin{array}{c}\text { Rata-rata ED } \\
(\mathrm{c})=(\mathrm{b}) /(\mathrm{a})\end{array}$ \\
\hline 1 & 150 & 40.000 & 2.587 & $6,47 \%$ \\
\hline 2 & 50 & 40.000 & 4.760 & $11,90 \%$ \\
\hline
\end{tabular}

Sumber : Data diolah (2017)

Berdasarkan hasil perhitungan efisiensi saluran distribusi ikan cakalang asap dapat dilihat bahwa seluruh saluran distribusi ikan cakalang asap di Kelurahan Girian Atas sudah efisien, karena hasil perhitungan nilai efisiensi distribusi seluruhnya jauh berada dibawah 50\%. Berdasarkan hasil perhitungan efisiensi distribusi, saluran dengan efisiensi yang paling tinggi adalah Saluran 1 (Pedagang ikan cakalang segar - Pengolah ikan cakalang asap - Konsumen) yaitu sebesar (6,47\%).Rata-rata volume pasokan harian yang tinggi yaitu sebesar 150 jepit/hari menjadikan biaya transaksi yang dikeluarkan pada ini memiliki nilai terendah, yakni Rp 2.587/ jepit.

$$
\text { Saluran dengan efisiensi }
$$

terendah adalah saluran 2 (Pedagang ikan cakalang segar - Pengolah ikan cakalang asap - Pedagang besar ikan cakalang asap - Pedagang pengecer ikan cakalang asap - Konsumen) yaitu $11,90 \%$. Saluran 2 merupakan saluran yang paling panjang dari 2 saluran distribusi yang ada. Rantai pasokan yang lebih panjang menjadikan biaya transaksi menjadi semakin tinggi. Biaya transaksi yang dikeluarkan sebesar Rp 4.760/jepit.

\section{Identifikasi Resiko Pelaku Rantai Pasok Ikan Cakalang Asap}

Identifikasi risiko pada setiap mata rantai pasokan ikan cakalang asap merupakan upaya untuk memperbaiki kinerja berdasarkan masalah yang dihadapi serta dampak yang akan ditimbulkan pada setiap mata rantai setelah jaringan distribusi tersebut dipetakan. Abdurrahman et. al. (2013) mengemukakan analisis risiko dilakukan untuk mengetahui tingkat atau besarnya risiko dan dampak terhadap kelangsungan proyek yaitu waktu serta respon resiko yang dilakukan. Langkah awal adalah melakukan analisis menggunakan severity index digunakan untuk menentukan nilai probabilitas dan 
dampak, lalu mengkategorikannya berdasarkan besar probabilitas dampaknya. Berdasarkan analisis severity index pada 5 (lima) pelaku rantai pasok, (a), pedagang ikan cakalang segar (b), pengolah ikan cakalang asap (c), pedagang besar ikan cakalang asap (d), pedagang pengecer ikan cakalang asap (e) dan konsumen diperoleh 18 risiko. Risiko yang terdapat pada Kuadran I berjumlah 8 risiko yang dapat mengancam kelangsungan rantai pasok. Kuadran II berjumlah 1 (satu) risiko dengan tingkat probabilitas dan dampaknya sedang. Kuadran III berjumlah 7 (tujuh) risiko dengan tingkat probabilitas rendah, namun dampaknya tinggi. Kuadran IV berjumlah 2 (dua) risiko dengan tingkat probabilitas rendah dan dampaknya kecil. Analisis perhitungan risiko berdasarkan pelaku rantai pasok dapat dilihat pada Lampiran 3. Peta risiko rantai pasok ikan cakalang asap di Kelurahan Girian Atas Kota Bitung dapat dilihat pada Gambar berikut.

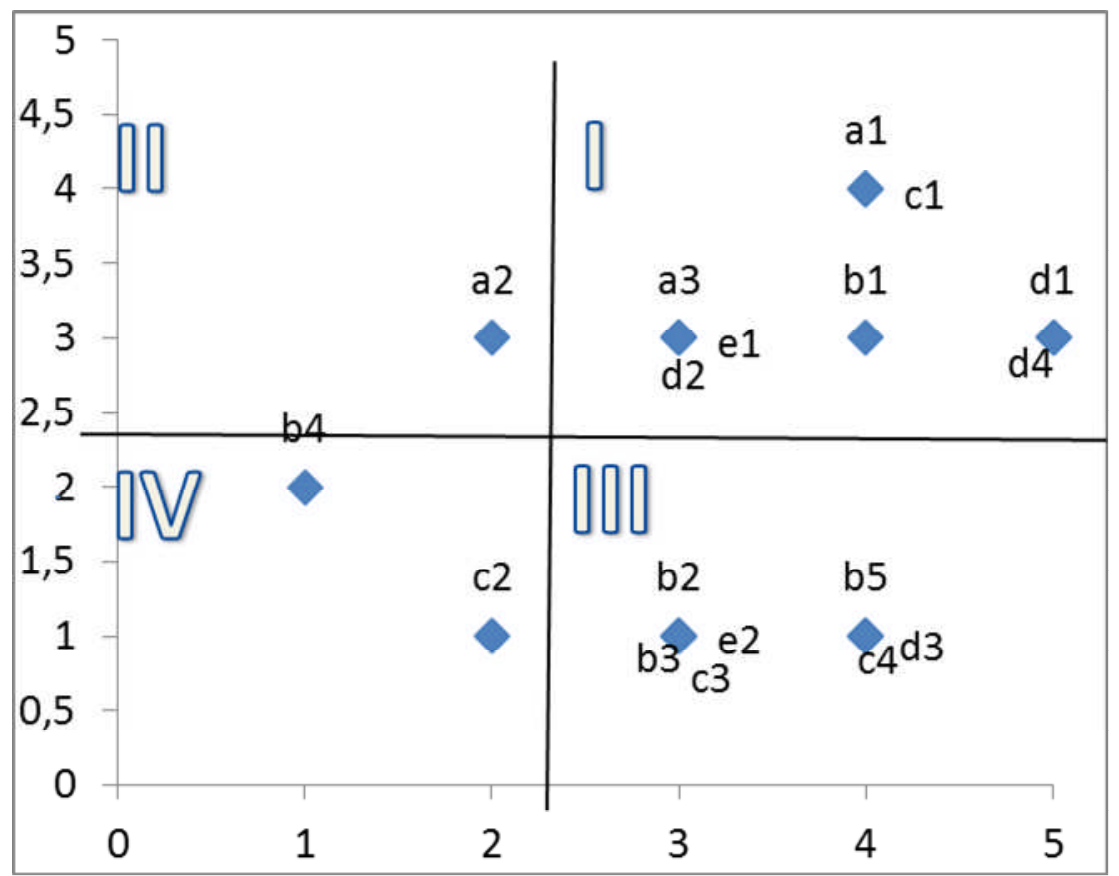

Gambar. Peta risiko rantai pasok ikan cakalang asap di Kelurahan Girian Atas Kota Bitung

Matriks antara probability dan severity menghasilkan empat kuadran utama. Risiko yang terdapat pada Kuadran I merupakan area dengan tingkat probabilitas sedang sampai tinggi dan tingkat dampak sedang sampai tinggi. Kuadran I terdiri dari risiko-risiko yang masuk ke dalam prioritas I atau prioritas utama. Risiko yang dialami oleh pedagang ikan cakang segar sebanyak 2 (dua) risiko yang terdapat pada Kuadran I, yaitu fluktuasi harga dan tidak dapat memenuhi permintaan. Pengolah ikan cakalang asap dengan 1 (satu) risiko, yaitu fluktusasi harga. Pedagang besar ikan cakalang asap dengan 1 (satu) risiko, yaitu fluktuasi harga, Pedagang pengecer dengan 3 (tiga) risiko, yaitu fluktuasi harga, produk tidak habis terjual dan tidak dapat memenuhi permintaan dan Konsumen 1 (satu) risiko yaitu fluktuasi harga.

Fluktuasi harga menjadi risiko yang sering dihadapi oleh pelaku rantai pasok ikan cakalang asap, maka perlu adanya campur tangan pemerintah dalam menstabilisasi harga pada pasar. Ketersediaan pasokan di pasar juga 
memengaruhi fluktuasi harga produk, oleh karena itu mengatur sistem distribusi dan diadakannya pasar murah juga diperlukan agar dapat memastikan tidak terjadi kekurangan terhadap produk ikan cakalang segar di pasar.

\section{KESIMPULAN}

Berdasarkan hasil penelitian ini dapat ditarik beberapa kesimpulan sebagai berikut:

1. Rantai pasok ikan cakalang asap di Kelurahan Girian Atas Kota Bitung terdiri dari 5 (lima) pelaku usaha, yaitu pedagang ikan cakalang segar, pengolah ikan cakalang asap, pedagang besar ikan cakalang asap, pedagang pengecer ikan cakalang asap dan rumah makan sebagai konsumen. Aliran keuangan yang mengalir dari pedagang ikan cakalang asap sampai konsumen terdapat dua cara pembayaran, yaitu pembayaran secara lunas, dan pembayaran secara tempo. Aliran informasi pada rantai pasok ikan cakalang asap berkaitan dengan stok, jumlah permintaan, harga ikan segar per kilogram maupun harga ikan cakalang asap per jepit.

2. Saluran distribusi ikan cakalang asap dengan efisiensi yang paling tinggi adalah Saluran $1(6,47 \%)$, yang terdiri dari pedagang ikan cakalang segar - pengolah ikan cakalang asap - konsumen) memiliki biaya transaksi terendah. Sedangkan
Saluran 2 yang terdiri dari pedagang ikan cakalang segar - pengolah ikan cakalang asap - pedagang besar ikan cakalang asap - pedagang pengecer ikan cakalang asap konsumen memiliki efisiensi yang lebih rendah $(11,90 \%)$. Secara umum kedua saluran distribusi telah masuk kategori efisien karena rasio rata-rata biaya transaksi terhadap rata-rata nilai produk kurang dari $50 \%$.

3. Analisis risiko yang terjadi pada pelaku rantai pasok berjumlah 18 risiko dari 5 (lima) pelaku rantai pasok. Fluktuasi harga menjadi risiko yang paling banyak terjadi pada seluruh pelaku rantai rantai pasok ikan cakalang asap di Kelurahan Girian Atas Kota Bitung.

\section{DAFTAR PUSTAKA}

Abdurrahman MAN, Panguriseng, Erwin B. 2012. Analisa Pengelolaan Risiko Proyek-Proyek Pengairan. Jurnal Teknik Sipil Universitas Hassanudin.

Dahuri R, Rais Y, Putra SG, Sitepu, M.J. 2001. Pengelolaan Sumber Daya Wilayah Pesisir dan Lautan Secara Terpadu. Jakarta: PT. Pradnya Paramita.

Dulay., Pasaribu., Kanisius. 2014. Pengolahan Tradisional Pengasapan Ikan Cakalang (Katsuwonus pelamis). Makalah Pribadi Dasar Teknologi Hasil Perairan. Manajemen Sumber Daya Perairan. Universitas Sumatera Utara.

Mulyadi, 2005. Akuntansi Biaya. Edisi Kelima. Yogyakarta ; UPPAMP YKPN Universitas Gajah Mada. 